\title{
Review
}

\section{A Review on Cancer Probability in Human Beings Due to Environmental Impact of Polycyclic Aromatic Hydrocarbons (PAHs) and Remediation}

\author{
Ayesha Jamal Zaidi*a, Hina Ahsan ${ }^{\mathrm{b}}$ and Alia Bano Munshia \\ ${ }^{a}$ Centre of Excellence in Marine Biology, University of Karachi, Karachi-75270, Pakistan. \\ ${ }^{b}$ PCSIR Labs. Complex, Karachi-75280, Pakistan.
}

(received December 19, 2019; revised January 04, 2021; accepted January 27, 2021)

\begin{abstract}
Environmental consequences of polycyclic aromatic hydrocarbons (PAHs) were studied to evaluate possible human health risks, subsequent cancer probabilities and remediation tools for their eradication. Polycyclic aromatic hydrocarbons (PAHs) are generated globally through incomplete combustion of organic materials and emitted in the environment by various anthropogenic routes including residential heating, coal gasification, liquefying plants, cooking practices, thermal distillation of petroleum and coal, oil spills, ships embankments, incomplete burning of fossil fuels, forest fires, asphalt, engines and vehicles exhaust. Their high lipophilicity and marked tendency for localization in body fats made them easily absorbed through dermis, nasal mucosa and gastrointestinal tract of mammals. The reviewed data show estimated carcinogenic potency equivalent concentrations exceeding the screened value for food stuffs including fish species indicating significant carcinogenic health risks associated with the consumption of fishes. Many remedial measures have been taken to exterminate persistent organic pollutants including PAHs out of which bio-remediation being comparatively safer and economical methodology.
\end{abstract}

Keywords: carcinogenic, saturated and unsaturated hydrocarbons (PAHs), fat and isolation

\section{Introduction}

Polycyclic aromatic hydrocarbons (PAHs) are a large group of organic compounds with two or more fused aromatic (benzene) rings found globally as mixtures in air, water and sediments. They occur naturally in fossil fuels or formed by the incomplete combustion of organic materials or coal gastification sites (Fig. 1) (Behera et al., 2018). PAHs are classified as persistent organic pollutants (POPs) and persistent, bio-accumulative and toxic (PBT) chemicals with various carcinogenic and mutagenic properties. Dietary sources are among the major route of exposures in humans among both smokers, non-smokers, occupational workers and nonoccupational persons mostly due to food processing techniques like curing, drying, smoking, roasting, grilling, barbecuing and refining. These food processing steps are known to generate and increase the level of PAHs in the food (WHO, 2000).

All these serious health issues avokes a great matter of concerned around the world and number of regional

*Author for correspondence;

E-mail: ayesha.jamal.zaidi2015@gmail.com conventions were held since 1970s to control over them and many legislations have been made. In consonance with US EPA and ATSDR 16 PAHs are listed as reasonably anticipated to be human carcinogen and included in EPA priority pollutant list (Table 1), (EPA, 2015; ATSDR, 2012). Scientific Committee on Food of European Union had also established some legislations regarding exposure of food stuffs by different PAHs sources (Table 2) (EC (SCF), 2011).

Sources and exposures to humans. Humans are exposed by PAHs through a variety of anthropogenic and natural sources by different routes specifically subsequent inhalation, digestion and skin contact (Fig. 4) (Qu et al., 2015). The sources includes forest fires, volcanic eruption, oil or natural gas seepage, mining of natural fuels and their destructive distillation, oil spills, incomplete organic fuel combustion, tobacco smoke, industrial by product emissions, contaminated food and different cooking practices (Fig. 2) (Masuda et al., 2019; Alomirah et al., 2011; Ramesh et al., 2011). This has been reported that realistic exposure to toxic chemicals occurs always in mixtures rather than by single chemical. 


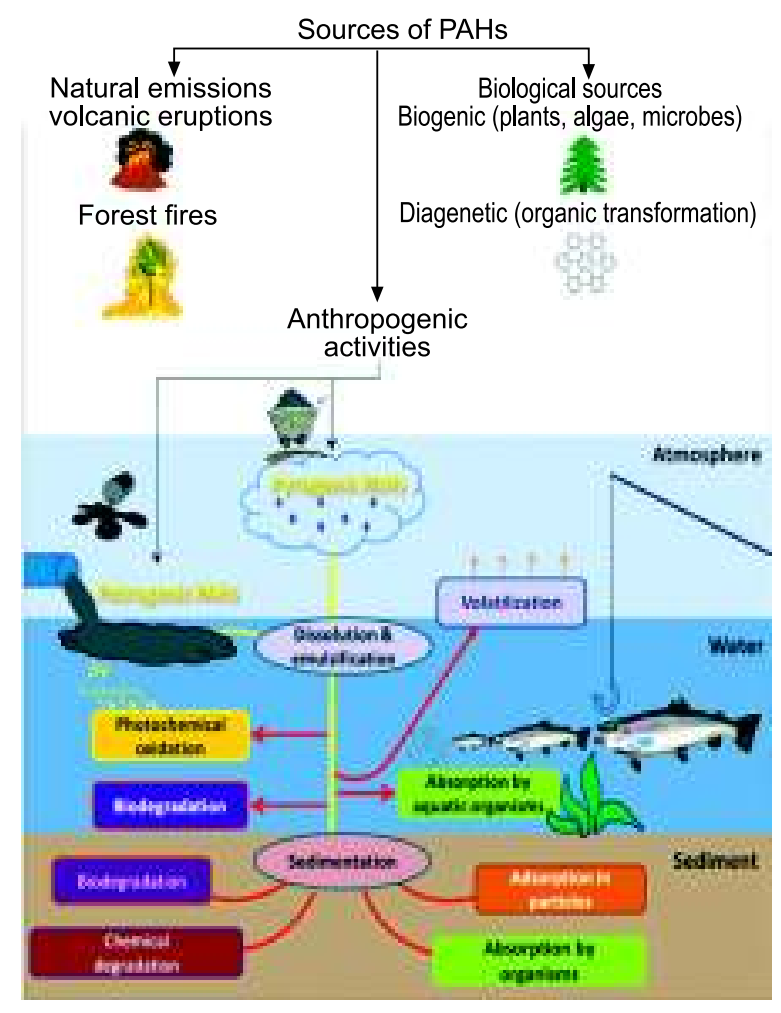

Fig. 1. Environmental sources of polycyclic aromatic hydrocarbons (Behera et al., 2018).

However, for study purposes single chemicals are being used and helpful in the research dominion. Therefore, preferably PAHs as mixtures are given more importance to study the interaction between each individual compound and their relevance to human health hazards and exposures. Polycyclic aromatic hydrocarbons (PAHs) are toxic semi volatile organic compounds (SVOCs) that partition between gas and aerosol phases and travel long distances in the atmosphere (Fig. 3) (Friedman et al., 2014; Wang et al., 2010). The PAHs become trapped in secondary organic aerosol (SOA) during its formation, preventing them from evapouration and degradation via oxidation (Zelenyuk et al., 2012). PAHs in the atmosphere decreases substantially due to accumulation of SOA species over particles during their atmospheric transport and chemical aging (Jariyasopit et al., 2014; Robinson et al., 2007; Finley et al., 1994). To find the clear impact of PAHs on environment the congested industrial areas has to be constantly monitored for pollution by the environmental protection agency (EPA) of respective countries.
Table 1. The carcinogenic classifications of selected PAHs by specific agencies (ATSDR, 2012)

\begin{tabular}{|c|c|c|}
\hline Agency & $\begin{array}{l}\text { (EPA, 2000) PAH } \\
\text { Compound(s) }\end{array}$ & $\begin{array}{l}\text { Carcinogenic } \\
\text { Classification }\end{array}$ \\
\hline $\begin{array}{l}\text { U.S. Department } \\
\text { of health and } \\
\text { human services } \\
\text { (HHS) }\end{array}$ & $\begin{array}{l}\text { - Benz(a)anthracene } \\
\text { - Benzo(b)fluoranthene } \\
\text { - Benzo(a)pyrene } \\
\text { - Dibenz(a,h)anthracene } \\
\text { - Indeno(1,2,3-c,d)pyrene }\end{array}$ & $\begin{array}{l}\text { Known animal } \\
\text { carcinogens }\end{array}$ \\
\hline \multirow{3}{*}{$\begin{array}{l}\text { International } \\
\text { agency for } \\
\text { research on } \\
\text { cancer (IARC) }\end{array}$} & $\begin{array}{l}\text { - Benz(a)anthracene } \\
\text { - Benzo(a)pyrene }\end{array}$ & $\begin{array}{l}\text { Probably carcinogenic } \\
\text { to humans }\end{array}$ \\
\hline & $\begin{array}{l}\text { - Benzo(a)fluoranthene } \\
\text { - Benzo(k)fluoranthene } \\
\text { - Indeno(1,2,3-c,d)pyrene }\end{array}$ & $\begin{array}{l}\text { Possibly carcinogenic } \\
\text { to humans }\end{array}$ \\
\hline & $\begin{array}{l}\text { - Anthracene } \\
\text { - Benzo(g,h,i)perylene } \\
\text { - Benzo(e)pyrene } \\
\text { - Chrysene } \\
\text { - Fluoranthene } \\
\text { - Fluorene } \\
\text { - Phenanthrene } \\
\text { - Pyrene }\end{array}$ & $\begin{array}{l}\text { Not classifiable as to } \\
\text { their carcinogenicity to } \\
\text { humans }\end{array}$ \\
\hline \multirow[t]{2}{*}{$\begin{array}{l}\text { U.S. } \\
\text { Environmental } \\
\text { protection agency } \\
\text { (EPA) }\end{array}$} & $\begin{array}{l}\text { - Benz(a)anthracene } \\
\text { - Benzo(a)pyrene } \\
\text { - Benzo(b)fluoranthene } \\
\text { - Benzo(k)fluoranthene } \\
\text { - Chrysene } \\
\text { - Dibenz(a,h)anthracene } \\
\text { - Indeno(1,2,3-c-d)pyrene }\end{array}$ & $\begin{array}{l}\text { Probable human } \\
\text { carcinogens }\end{array}$ \\
\hline & $\begin{array}{l}\text { - Acenaphthylene } \\
\text { - Anthracene } \\
\text { - Benzo(g,h,i)perylene } \\
\text { - Fluoranthene } \\
\text { - Fluorene } \\
\text { - Phenanthrene } \\
\text { - Pyrene }\end{array}$ & $\begin{array}{l}\text { Not classifiable as to } \\
\text { human carcinogen }\end{array}$ \\
\hline
\end{tabular}

For example Gadani in Balochistan province of Pakistan was designated as the world's third largest ship-breaking yard in the 1980s. The ship-breaking operations polluted the environment following several decades due to which subsurface soil, groundwater and sediments are contaminated with PAHs and a variety of pollutants, including dioxins and several heavy metals, reported during the human health and ecological risk assessments. Ship-breaking activities are sources of atmospheric emission of PAHs and high concentrations of PAHs have been found in ambient air in Chittagong in comparison to those found in similar studies performed in other parts of Asia (Nøst et al., 2015). Estimated 


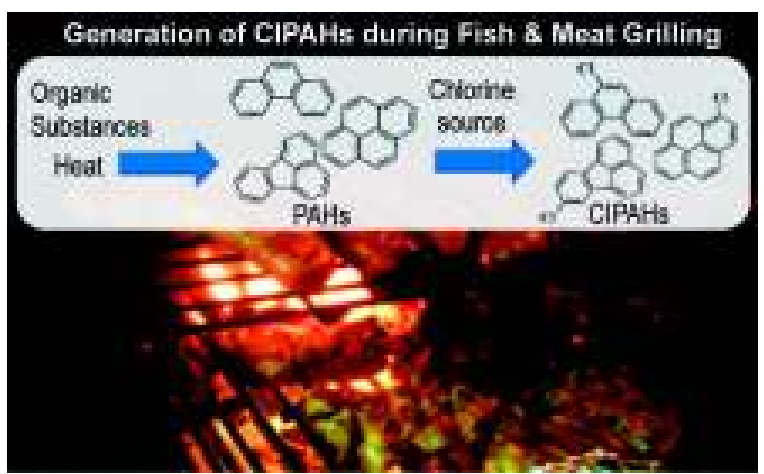

Fig. 2. Cooking impact of PAHs and its derivatives chlorinated polycyclic aromatic hydrocarbons (ClPAHS) (Masuda et al., 2019).

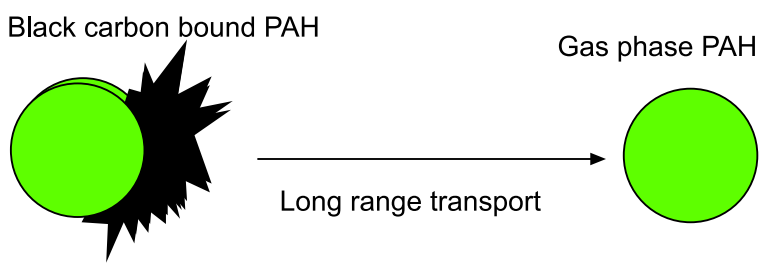

Fig. 3. Influence of secondary organic aerosol (SOA) on long-range atmospheric polycyclic aromatic hydrocarbon transport (Friedman et al., 2014).

toxic equivalent quotients indicate elevated human health risks caused by inhalation of PAHs at most sites. Similarly Clifton beach of Karachi has shown the most polluted site after Tasman spirit oil spill (Janjua et al., 2013; Meo et al., 2009). Thus exposure to PAHs either directly or indirectly causes severe health issues in humans depending on the nature of contact with the oil spill means either through respiration in polluted air, skin contact and indirectly bathing in contaminated water or eating contaminated food. Extremely high levels of PAHs were measured in Clifton beach sediments after a period of first sampling of Tasman spirit oil spill and this site was found to be one of the most highly PAHs contaminated sites in the world relative to other areas and worldwide estuaries of concern (Siddiqi and Munshi, 2015).

The Clifton beach provides an opportunity to study a complex PAH mixtures that may represent world exposure scenario for decade. No doubt, it is a great need to analyze and mitigate risks due to PAHs exposure, which has numerous human health consequences. All

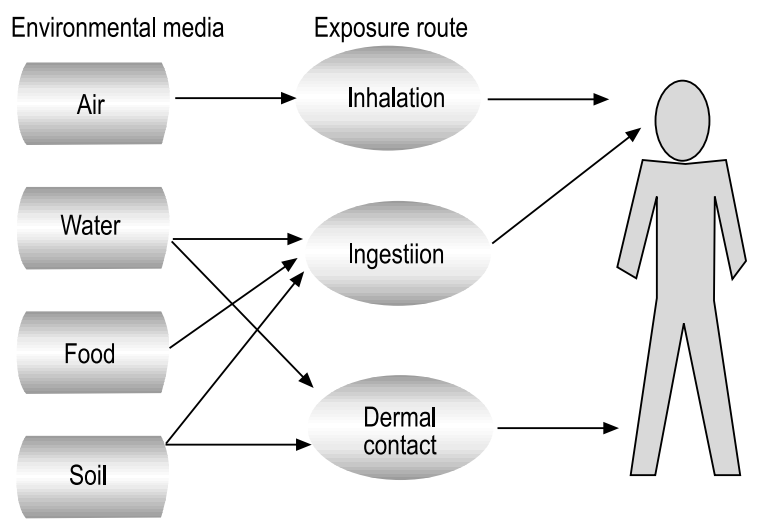

Fig. 4. Multipath ways of human exposure to polycyclic aromatic hydrocarbons $(\mathrm{Qu}$ et al., 2015).

matrices like sediments, seawater, marine fauna and flora than air must be analyzed for their contribution to PAH exposure, which may have a large impact on dietary exposures to PAHs. Higher concentration of PAHs and the complexity of the mixture have proved that many PAHs are carcinogenic. The sedimentderived PAH mixture components would cancer relevant and confer cancer risk through various activities (e.g., fishing) relevant to sediment exposure. A model complex PAH mixture that may occur in other regions can cause increased cancer risk and detrimental health effects. A common method can be utilized successfully to estimate PAHs exposure (Fillmann et al., 2004) and other urinary biomarkers across the Pakistan with a statistical weighted approach (Sobus et al., 2015). Efforts have been done to enhance the capabilities to estimate and rank demographic subpopulations by PAHs exposure, targeting those with high exposure. PAHs mixtures have posed significant impact on public health risks by the potential to increase cancer risk in the general population, especially for vulnerable and highly exposed populations being ubiquitous environmental toxicants.

PAHs are supposed to be endocrine disrupting chemicals and their exposure is most threatful for human beings from prenatal days until death (Miller and Jones, 2013). It has been noted that workers exposed to mixtures of PAHs possess increased risk of skin, lung, bladder and gastrointestinal cancers and long-term exposure to low levels of some PAHs may cause cancer such as Benzo (a) pyrene which 
Table 2. The annex to regulation (EC) No 1881/2006 is amended as follows; Section 6: "polycyclic aromatic hydrocarbons" (EC (SCF), 2011)

\begin{tabular}{|c|c|c|c|}
\hline \multicolumn{2}{|c|}{ Foodstuffs } & \multicolumn{2}{|l|}{ Maximum Limits $\mu \mathrm{g} / \mathrm{Kg}$} \\
\hline 6.1 & $\begin{array}{l}\text { Benzo(a)pyrene, benz(a)anthracene, Benz(b)fluoranthene } \\
\text { and chrysene }\end{array}$ & Benzo(a)pyrene & $\begin{array}{l}\text { Sum of Benzo(a)pyrene, } \\
\text { Benz(a)anthracene, } \\
\text { Benz(b)fluoranthene and } \\
\text { chrysene }\end{array}$ \\
\hline 6.1 .1 & $\begin{array}{l}\text { Oils and fats (excluding coca butter and coconut oil)intended } \\
\text { for direct human consumption or use as an ingredient in food }\end{array}$ & 2.0 & 10.0 \\
\hline 6.1 .2 & Cocoa beans and derived products & $\begin{array}{l}5.0 \mu \mathrm{g} / \mathrm{Kg} \text { fat as from } \\
1.4 .2013\end{array}$ & $\begin{array}{l}35.0 \mu \mathrm{g} / \mathrm{Kg} \text { fat as from } \\
1.4 .2013 \text { until } 31.3 .2015 \\
30.0 \mu \mathrm{g} / \mathrm{Kg}\end{array}$ \\
\hline 6.1 .3 & $\begin{array}{l}\text { Coconut oil intended for direct human consumption or use } \\
\text { as an ingredient in food }\end{array}$ & 2.0 & 20.0 \\
\hline 6.1 .4 & Smoked meat and smoked meat products & $\begin{array}{l}5.0 \text { until } 31.8 .2014 \\
2.0 \text { as from } 1.9 .2014\end{array}$ & $\begin{array}{l}30.0 \text { as from } 1.9 .2012 \text { until } \\
31.12 .2014 \\
12.0 \text { as from } 1.9 .2014\end{array}$ \\
\hline 6.1 .5 & $\begin{array}{l}\text { Muscle meat of smoked fish and smoked fishery products } \\
\left(\left(^{25}\right)\left({ }^{36}\right) \text {, excluding fishery products listed in points } 6.1 .6 \text { and }\right. \\
6.1 .7 \text {. The maximum levels of smoked crustaceans applies } \\
\text { to muscle meat from appendages and abdomen }\left({ }^{44}\right) \text {. In case } \\
\text { of crabs and crab like crustaceans (Brachyura and Anomura) } \\
\text { it applies muscle meat from appendages. }\end{array}$ & $\begin{array}{l}5.0 \text { until } 31.8 .2014 \text { and } \\
2.0 \text { as from 1.9.2014 }\end{array}$ & $\begin{array}{l}30.0 \text { as from } 1.9 .2012 \text { until } \\
31.8 .2014 \\
12.0\end{array}$ \\
\hline 6.1 .6 & $\begin{array}{l}\text { Smoked sprats and canned smoked sprats }\left({ }^{25}\right)\left({ }^{47}\right)(\text { sprattus } \\
\text { sprattus) bivalve mollusk (fresh, chilled or frozen) }\left({ }^{26}\right) \text { heat } \\
\text { treated meat and heat treated meat products }\left({ }^{46}\right) \text { sold to the } \\
\text { final consumer }\end{array}$ & 5.0 & 30.0 \\
\hline 6.1 .7 & Bivalve mollusks $\left({ }^{36}\right)$ (smoked) & 6.0 & 35.0 \\
\hline 6.1 .8 & $\begin{array}{l}\text { Processed cereal based foods and baby foods for infants and } \\
\text { young children }\left(\left(^{3}\right)\left({ }^{29}\right)\right.\end{array}$ & 1.0 & 1.0 \\
\hline 6.1 .9 & $\begin{array}{l}\text { Infant formula and follow-on formulate, including infant } \\
\text { milk and follow-on milk }\left({ }^{8}\right)\left({ }^{29}\right)\end{array}$ & 1.0 & 1.0 \\
\hline 6.1 .1 .0 & $\begin{array}{l}\text { Dietary foods for special medical purposes }\left({ }^{9}\right)\left({ }^{29}\right) \text { intended } \\
\text { specifically for infants }\end{array}$ & 1.0 & 1.0 \\
\hline
\end{tabular}

$\left({ }^{45}\right)$ Lower bound concentrations are calculated on the assumption that all the values of the four substances below the level of quantification are zero

$\left({ }^{46}\right)$ Meat and meat products that have undergone a heat treatment potentially resulting in formation of PAH, i.e. only grilling and barbecuing

$\left({ }^{47}\right)$ For the canned product analysis shall be carried out on the whole content of the can. As regards the maximum levels for the whole composite product Art. (2)(1)(c) and 2(2) shall apply." (2) Endnote $\left({ }^{35}\right)$ is deleted

is the most common PAH to cause cancer in humans (Rengarajan et al., 2015).

Mechanism of cellular metabolism plays an important role in the conversion of chemical carcinogens into reactive species that damage cellular macromolecules and interfere with signaling pathways that cause cancer (Laffon et al., 2016). Human colon cells were known to metabolize PAHs and implants the toxic impacts on humans. This review compiles all necessary information available about PAHs, its chronic health hazards and human cancer risks. Health outcomes are addressed in the following categories in this review: physiological effects, genotoxicity, immunotoxicity, carcinogenicity, endocrine toxicity. 
Physiological impacts in humans. PAHs can make their way into the human's body through various routes that is inhalation, dermal contact and ingestion. Monte Carlo Simulation techniques have been widely used to provide quantitative estimates of probabilities of exposure and health risks (Table 3) (Qu et al., 2015). They are highly lipophilic and easily absorb through mucosal membrane of humans and their toxicity depends exclusively on their biotransformation to toxic metabolites and their interactions at the level of key metabolism enzymes. Induction of metabolism by one PAH may enhance the toxicity of another on the other hand the inhibition of the metabolic enzymes may decrease the toxicity of PAHs metabolites. They possessed adverse effects on human's immune system development, humoral immunity and host resistance (Tarafdar et al., 2020; Abdel-Shafy and Mansour, 2015). The mixed function oxidase enzyme systems are primarily responsible for PAHs metabolism and the first reaction is the formation of epoxides in the human cells. These epoxides then conjugated with glutathione at the detoxification step. The un-conjugated epoxides are converted into phenols and diols that has to be conjugated glucorunic acid or sulfuric to enable excretion (Fig. 5) (Behera et al., 2018).

Genotoxicity. A number of PAHs are mutagenic and genotoxic, depending on compound and induce DNA adduct formation in vitro and in vivo (Fig. 6). Some PAHs probably cause mutations in a number of genes that contribute to cancer development for example the anti-diol-epoxide of $\mathrm{B}[a] \mathrm{P}(( \pm)$-anti-BPDE). In human studies, lung tumors from non-smokers exposed to PAHs rich coal combustion emissions had mutations at guanine in K-ras codon 12 and p53 genes (Rengarajan et al., 2015).

Table 3. Risk parameters used for monte carlo simulation (Qu et al., 2015)

\begin{tabular}{|c|c|c|c|c|c|c|}
\hline Parameter & Symbol & Units & Infants & Children & Adults & References \\
\hline \multicolumn{7}{|l|}{ Population parameter } \\
\hline Age & & Year & $0-1$ & $2-18$ & $19-70$ & \\
\hline \multirow[t]{2}{*}{ Body weight } & $\overline{\mathrm{BW}}$ & $\mathrm{Kg}$ & $6.79 \pm 1.27$ & $37.3 \pm 9.1$ & $58.7 \pm 12.0$ & Chen and Liao (2006) \\
\hline & & & & & & Xiao et al. (2005) \\
\hline \multicolumn{7}{|l|}{ Inhalation parameter } \\
\hline Inhalation rate & $\mathrm{IR}_{\mathrm{a}}$ & $\mathrm{m}^{3} /$ day & $5.05 \pm 0.49$ & $9.67 \pm 2.39$ & $12.44 \pm 1.27$ & Wang et al. (2009) \\
\hline \multicolumn{7}{|l|}{ Ingestion parameter } \\
\hline Ingestion rate of water & $\mathrm{IR}_{\mathrm{w}}$ & $\mathrm{mL} / \mathrm{day}$ & $283.25 \pm 91.48$ & $497.35 \pm 138.28$ & $1,366 \pm 728$ & USEPA $(1997,2008)$ \\
\hline Ingestion rate in soil & $\mathrm{IR}_{\mathrm{s}}$ & $\mathrm{mg} / \mathrm{day}$ & $0-30$ & $24 \pm 4$ & $25(0.1-50)$ & Stanek et al. (2001), \\
\hline & & & & & & $\begin{array}{l}\text { USEPA (2008), } \\
\text { LaGoy (1987) }\end{array}$ \\
\hline Ingestion rate in fish & $\mathrm{IR}_{\mathrm{f}}$ & $\mathrm{mg} /$ day & $4.16 \pm 2.37$ & $27.45 \pm 5.52$ & $61.25 \pm 13.8$ & \\
\hline \multicolumn{7}{|l|}{ Dermal parameter } \\
\hline Total skin surface area & $A_{\text {bath }}$ & $\mathrm{m}^{2}$ & $0.39 \pm 0.05$ & $1.09 \pm 0.37$ & $1.67 \pm 0.10$ & Wang et al. (2008) \\
\hline Exposed skin surface & $A_{\mathrm{s}}$ & $\mathrm{cm}^{2}$ & $719 \pm 1.19$ & $860(430-2,160)$ & 1,530 & Wang et al. (2008) \\
\hline area & & & & & $(760-4,220)$ & Chen and Liao (2006) \\
\hline Soil to skin adherence & $\mathrm{AF}$ & $\mathrm{mg} / \mathrm{cm}^{2}$ & 0.04 & $0.65 \pm 1.2$ & $0.49 \pm 0.54$ & USEPA (2004), \\
\hline factor & & /day & & & & Finley et al. (1994) \\
\hline Time for shower & $t$ & $\min /$ day & 15 & $18.41 \pm 1.32$ & $10.4(3-61$ & USEPA $(1997,2008)$ \\
\hline $\begin{array}{l}\text { Dermal absorption } \\
\text { factor }\end{array}$ & ABS & Unitless & 0.13 & 0.13 & 0.13 & USEPA (2004) \\
\hline $\begin{array}{l}\text { Dermal permeability } \\
\text { coefficient }\end{array}$ & $K_{\mathrm{p}}$ & $\mathrm{cm} / \mathrm{h}$ & 0.7 & 0.7 & 0.7 & USEPA (2004) \\
\hline \multicolumn{7}{|l|}{ Risk model parameter } \\
\hline Exposure frequency & $\mathrm{EF}$ & Days/year & $345(180-365)$ & $345(180-365)$ & $345(180-365)$ & Smith (1994) \\
\hline Averaging time & $\mathrm{AT}$ & Days & 25,550 & 25,550 & 25,550 & USEPA (997) \\
\hline Exposure duration & ED & year & 1 & 17 & 52 & USEPA $(1997,2008)$ \\
\hline
\end{tabular}

The mean and standard deviation were used for lognormal distributions, minimum and maximum for uniform distributions and mean, minimum for triangular distributions. 


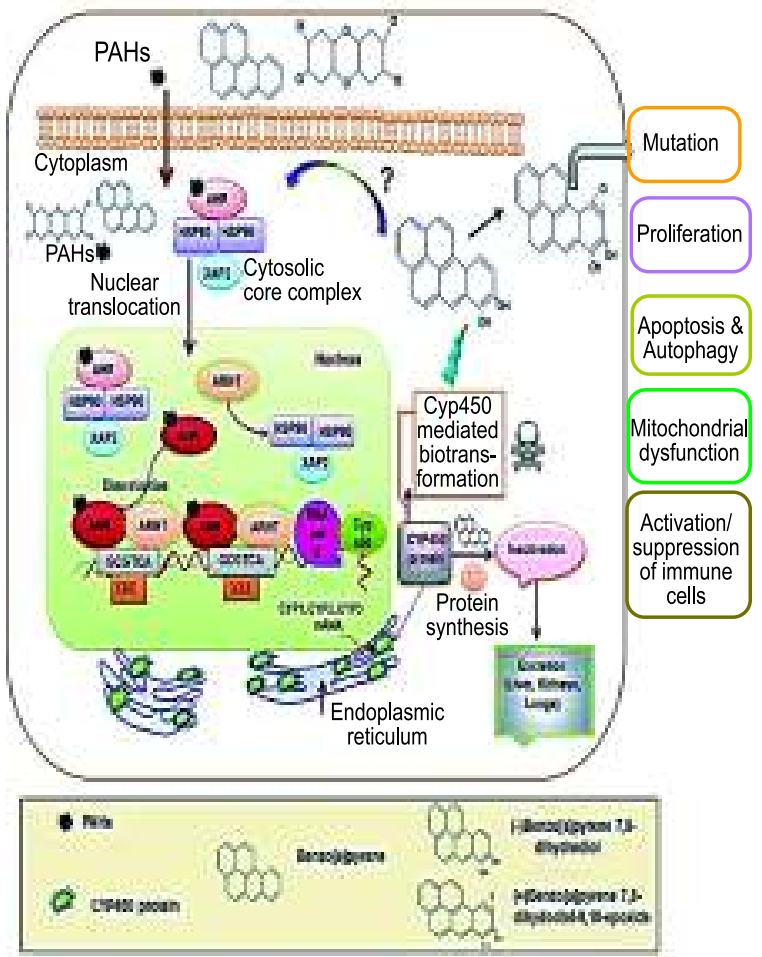

Fig. 5. Toxic multi-pathways of polycyclic aromatic hydrocarbons (Behera et al., 2018).

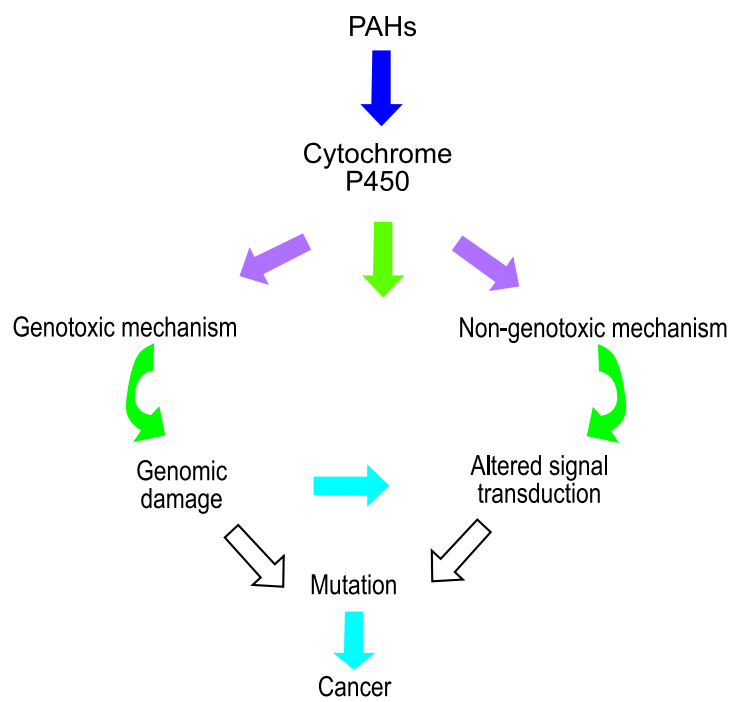

Fig. 6. Genotoxicity/mutagenicity \& carcinogenicity of polycyclic aromatic hydrocarbons.

Immunotoxicity. The immune system is the common target for PAH-toxic effects and for this reason PAHimmunogenicity or immunotoxicity has been widely examined in different studies using human cell lines and animal models. Immunotoxicity of PAHs on human beings has been evaluated and it has been examined that human $\mathrm{T}$ cells are highly sensitive to suppression of mitogen-effects of PAHs. B (a) P and DMBA are found highly immunotoxic in human system and showed suppression of T lymphocyte mitogenesis (Sakshi and Haritash, 2020).

Carcinogenicity. PAHs with 4 to 7 rings are found to be carcinogenic in experimental animals such as $\mathrm{B}[a] \mathrm{P}$ that induced tumors after exposure to PAHs in mice, rats, rabbits, hamsters and monkeys (EPA, 2015). Like other toxic chemicals, PAHs are also carcinogenic accumulants in both finfish and shellfish, binding to lipid molecules in muscles or tissues. Bioavailability and bio-transformation influenced mechanisms of cancer processes for disposition of PAHs in the body (Copat et al., 2013).

The organic fuel is a major source of PAHs contamination in food, generated particularly in unvented stoves cooking practices for example charring meat or deep frying, that can imposed carcinogenic effects by oral route exposures (Fig. 2) (Masuda et al., 2019; Balcioglu, 2016). The nonmetabolized PAHs are converted into reactive oxygen species such as epoxides and dihydrodiols, forming linkages to cellular proteins and DNA. The resulting biochemical disruptions and cell damage lead to mutations, developmental malformations, tumors and different types of cancers (Fig. 5) (Behera et al., 2018; Wu et al., 2012).

Data sources from occupational studies indicates that mixtures of PAHs are carcinogenic to humans, predominantly causing skin and lung cancers but also bladder and gastrointestinal cancers in some cases. However, it is not clear from these studies whether exposure to PAHs was the main cause, as these workers had been simultaneously exposed to other cancer causing agents (e.g., aromatic amines) Table 4 (Helmfrid et al., 2019). The studies on laboratory animals indicates that exposure to high levels of certain PAHs over a long period of time developed lung cancer from inhalation, stomach cancer from ingesting PAHs in food and skin cancer from skin contact. It is clear from ongoing research that $\mathrm{BaP}$ is the most common PAH that cause cancer in animals and is notable for being the first chemical carcinogen to have been discovered (Sakshi and Haritash, 2020; Abdel-Shafy and Mansoor, 2015; Rengarajan et al., 2015). 
Table 4. Basic characteristics of the study population. A restriction criterion of at least five years of residence time in the contaminated area, within $2 \mathrm{~km}$ from glass work (controls) and a latency time of at least 10 years between first residence year and time of diagnosis (cases) were applied. In the subsample taking part in the biomonitoring study, study participants who at the time of sampling lived within a geographical distance of $50 \mathrm{~km}$ were included. Significant differences $(\mathrm{P}<0.05)$ in bold. (Helmfrid et al., 2019)

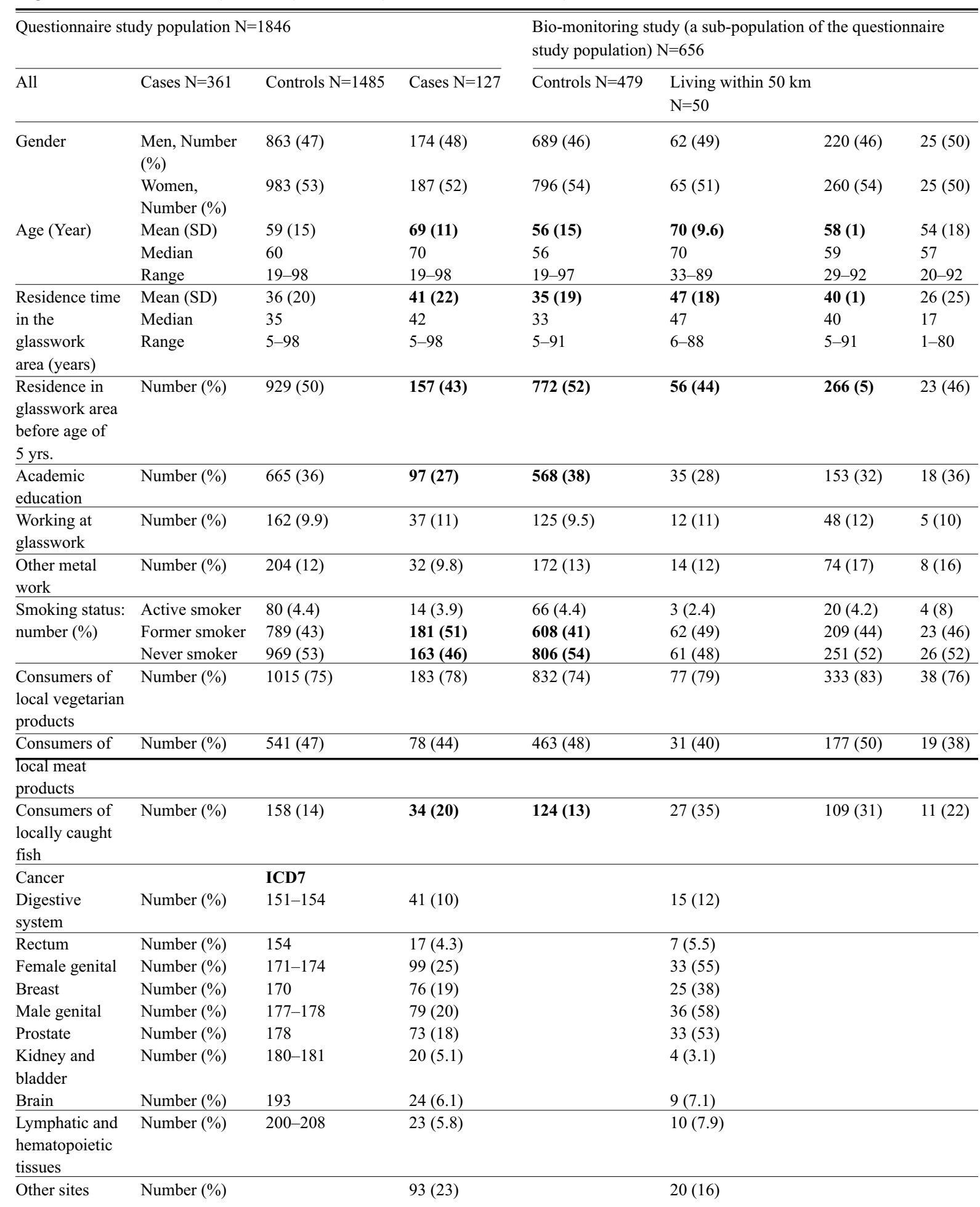

aparticipants taking part in the biomonitoring study who lived outside the $2 \mathrm{~km}$ radius but within $50 \mathrm{~km}$ of glassworks at the time of biological sampling. 
The enzyme systems involved in the metabolism of carcinogenic PAHs includes cytochrome P450 enzymes, CYP 1A1, 1A2, 1B1 and 3A4. In some case studies, specific mutations found in the Tp53 gene, the most commonly mutated gene in human cancers, associated with exposure to certain carcinogens. For example, the PAHs in cigarette smoke bind preferentially to the Tp53 gene sites called "hotspot" codons, where most smoking associated mutations are also found. Such studies give support to the link between DNA adducts and the cancer risk in humans (Rengarajan et al., 2015). The International Agency for Research on Cancer and the US EPA classified a number of PAHs as carcinogenic to animals and some PAH-rich mixtures as carcinogenic to humans Table 1 and 2 (EPA, 2015; ATSDR, 2012).

Endocrine toxicity. PAHs undergoes number of compositional changes and found to be endocrine disrupting chemicals in many epidemiological studies in humans cell lines. The type of function effected and associated doses vary with the alkylation status of PAHs (Lee et al., 2017). Estrogen signaling is one of the most studied pathways associated with the endocrinedisrupting activities of PAHs and involves estrogen receptors and aryl hydrocarbon receptors. However, some of the actions of PAHs are contradictory, complex, and un-explainable. Although several possibilities have been suggested, such as direct interactions between PAHs and their receptors and the suppression of their activities through other pathways. The mechanisms underlying the activities of PAHs remain unclear. So, standardized assay protocols for pathway based assessments are considered to be important to overcome these issues (Zhang et al., 2016).
Remediation. Many physical and chemical procedures have been used for the remediation of PAHs at oil polluted sites but most of them were found to be challenging, expensive and formed secondary contaminants. Elimination of PAHs from air, water bodies and sediments can take place by means of volatization, photo oxidation, chemical oxidation, bioaccumulation, adsorption, microbial degradation and their adhesion to the soil matrix (Fig. 7) (Abdul-Shafy and Mansour, 2015). The physical characteristics of PAHs such as increasing molecular weight, increased number of rings, insignificant water solubility and high octanol-water partition coefficient decides their availability in the environment and selection of eradication tool (Gaur and Narasimhulu, 2018; Gitipour et al., 2018).

Apart from these bio-remediation is found to be the most effective, cost efficient and environmental friendly technique. Many aerobic and anaerobic micro-organisms including bacteria (gram-positive and gram negative), fungi, and algae possess the ability to utilize PAHs as energy source. PAH-bio-degradation could be achieved when microbial species are present in favourable environmental conditions of temperature, $\mathrm{pH}$, nutrients and metabolites (Sakshi and Haritash, 2020). The studies have revealed that the most prominently studied microorganisms for PAH-degradation are bacteria followed by fungi and algae. The bio-degradation involves biotransformation of PAHs compounds into simpler metabolic species and also include mineralization of organic compounds into inorganic minerals either aerobically that is $\mathrm{H}_{2} \mathrm{O}$ and $\mathrm{CO}_{2}$ or anaerobically such as $\mathrm{CH}_{4}$ (Fig. 8) (Sakshi and Haritash, 2020; Babu et al., 2019; Kuppusamy et al., 2017; Shahsavari et al., 2014). Table 5 shows some advantages and dis-

Table 5. Advantages and disadvantages of bio-remediation techniques (Shahsavari et al., 2014)

\begin{tabular}{|c|c|c|c|}
\hline Technology & Key points & Advantages & Disadvantages \\
\hline Natural attenuation & $\begin{array}{l}\text { Using indigenous micro- } \\
\text { organisms and natural } \\
\text { condition }\end{array}$ & Cheapest technology & $\begin{array}{l}\text { Requires extensive long-term } \\
\text { monitoring } \\
\text { Not always successful }\end{array}$ \\
\hline Bio-augmentation & $\begin{array}{l}\text { Addition of hydrocarbon- } \\
\text { degrading micro-organisms }\end{array}$ & $\begin{array}{l}\text { Using high biomass of } \\
\text { hydrocarbonoclastic micro- } \\
\text { organisms }\end{array}$ & $\begin{array}{l}\text { Changes the natural microbial } \\
\text { structure } \\
\text { Poor adaptation of } \\
\text { hydrocarbonoclastic micro- } \\
\text { organisms to the contaminated } \\
\text { site }\end{array}$ \\
\hline Bio-stimulation & Addition of nutrient & $\begin{array}{l}\text { More efficient than natural } \\
\text { attenuation }\end{array}$ & Not always successful \\
\hline Phytoremediation & $\begin{array}{l}\text { Using plants and their } \\
\text { associated micro-organisms }\end{array}$ & $\begin{array}{l}\text { Supports hydrocarbonoclastic } \\
\text { micro-organisms within plant root }\end{array}$ & $\begin{array}{l}\text { Toxicity of contaminants to the } \\
\text { plant }\end{array}$ \\
\hline
\end{tabular}




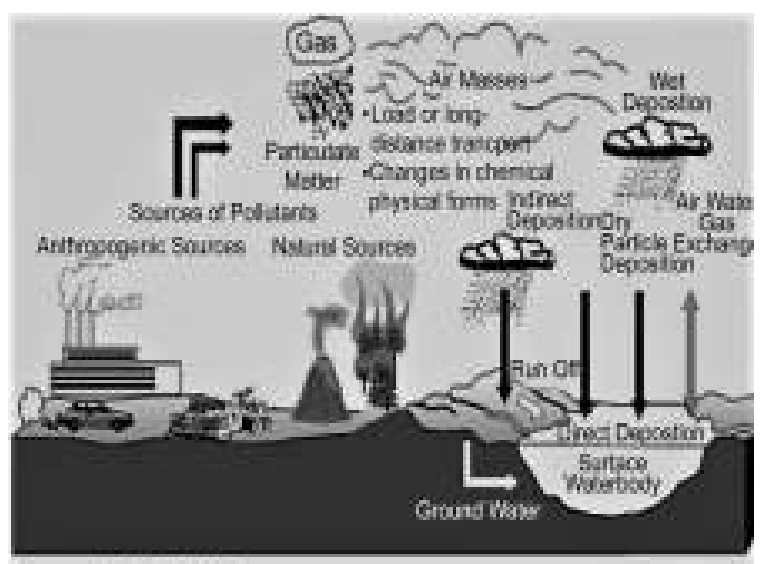

Souve:U.S. EPS. 2080

Fig. 7. Elimination of PAHs from the Environment (Abdul-Shafy and Mansour, 2015).

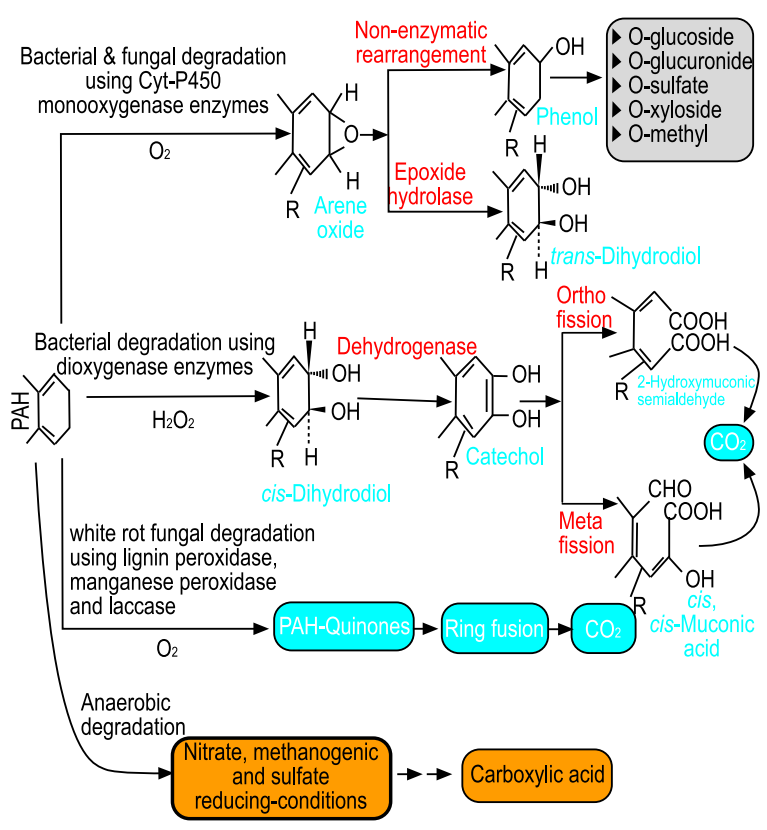

Fig. 8. Bio-degradation pathways of bacteria and fungi (Shahsavari et al., 2014).

advantages of bacterial and fungal bio-degradation processes (Shahsavari et al., 2014).

\section{Conclusion}

Epidemiological exposure. The environmental factors play an important role in cancer susceptibility as an association between ingestion of PAHs and esophageal cancer (Chen and Liao, 2006; Kamangar et al., 2005). This can be concluded that the high levels of carcinogenic PAHs in food and indoor air pollution (domestic cheating with coal) have been implicated as the causative factors for esophageal cancer. It is reported that cancer is promoted by the increased intake of PAHs through dietary fat and dietary $\mathrm{B}(\mathrm{a}) \mathrm{P}$ consumption which is a major risk factor for cancer (Yebra-Pimentel et al., 2015; Tabatabaei et al., 2010), and the existing data gaps and scope for future studies is also has to be emphasized. This information is also expected to stimulate research on mechanisms of sporadic cancers caused by exposure to environmental carcinogens. Therefore, proper estimations of dietary and nondietary exposures could help accurately in assessing the risk of exposure to PAHs through diet.

Conflict of Interest. The authors declare no conflict of interest.

\section{References}

Abdel-Shafy, H.I., Mansoor, M. 2015. A review on polycyclic aromatic hydrocarbons; source, environmental impact, effect on human health and remediation. Egyptian Journal of Petroleum, 25: 107-123.

Alomirah, H., Al-Zenki, S., Al-Hooti, S., Zaghloul, S. 2011. Concentrations and dietary exposure to polycyclic aromatic hydrocarbons (PAHs) from grilled and smoked foods. Food Control, 22: 20282035.

ATSDR, 2012. Case Studies in Environmental Medicine Toxicity of Polycyclic Aromatic Hydrocarbons (PAHS). U.S. Department of Health and Human Services, Agency for Toxic Substances and Disease Registry, Division of Toxicology and Environmental Medicine, Environmental Medicine and Educational Services Branch, pp. 1-68, USA.

Babu, A.G., Reja, S.I., Akhtar, N., Sultana, M., Deore, P.S., Ali, F.I. 2019. Bio-remediation of polycyclic aromatic hydrocarbons (PAHs); current practices and outlook. In: Microorganisms for Sustainability, Arora, P. (ed.), vol. 10, pp. 189-216, Springer, Singapore.

Balcioglu, E.B. 2016. Potential effects of polycyclic aromatic hydrocarbons (PAHs) in marine foods on human health: a critical review. Toxin Reviews, 35: 98-105.

Behera, K.B., Das, A., Sarkar, D.J., Weerathanji, P., Parida, P.K., Das, B.K., Thavamani, P., Ramanathan, R., Bansal, V. 2018. Environmental Pollution, 241: 
212-233.

Chen, S.C., Liao, C.M. 2006. Health risk assessment on human exposed to environmental polycyclic aromatic hydrocarbons pollution sources. Science of the Total Environment, 366: 112-123.

Copat, C., Conti, G.O., Signorelli, C., Marmiroli, S., Sciacca, S., Vinceti, M., Ferrante, M. 2013. Risk assessment for metals and PAHs by mediterranean seafood. Food and Nutrition Sciences, 4: 10-13.

EC (SCF). 2011. European Commission Regulation (EU) NO 835/2011of 19 August 2011 Amending Regulation (EC) No 1881/2006 as Regards Maximum Levels for Polycyclic Aromatic Hydrocarbons in Foodstuffs Text with EEA Relevance, OJL 215, 20.8.2011, pp. 4-8. European Commission, Health, and Consumer Protection Directorate-General., Brussels.

EPA. 2015. EPA Priority Pollutant List, pp. 1-2. United States Environmental Protection Agency. USA. Fillmann, G., Watson, G.M., Howsam, M., Francioni, E., Depledge, M.H., Readman, J.W. 2004. Urinary PAH metabolites as biomarkers of exposure in aquatic environments. Environmental Science \& Technology, 38: 2649-2656.

Finley, B.L., Scott, P.K., Mighthall, D.A. 1994. Development of a standard soil-to-skin adherence probability density-function for use in Monte-Carlo analyses of dermal exposure. Risk Analysis, 14: 555-569.

Friedman, C.L., Pierce, J.R., Selin, N.E. 2014. Assessing the influence of secondary organic versus primary carbonaceous aerosols on long-range atmospheric polycyclic aromatic hydrocarbon transport. Environmental Science \& Technology, 48: 32933302.

Gaur, N., Narasimhulu, K., Pydisetty, Y. 2018. Recent advances in bio-remediation of persistent organic pollutants and its effects on environment. Journal of Cleaner Production, 198: 1602-1631.

Gitipour, S., Sorial, G.A., Ghasemi, S., Bazyari, M. 2018. Treatment technologies for PAHcontaminated sites: a critical review. Environmental Monitoring and Assessment, 190: 546.

Helmfrid, I., Ljunggren, S., Nosratabadi, R., Augustsson, A., Filipsson, M., Frederickson, M., Karlsson, H., Berglund, M. 2019. Exposure of metals and PAH through local foods and risk of cancer in a historically contaminated glassworks area. Environment International, 131: 104985-94.

Janjua, N.Z., Kadir, M.M., Lutfi, S., Tipre, M.,
Sathiakumar, N. 2013. Tasman spirit oil spill in Pakistan - Research Response and Lessons Learned. American Journal of Industrial Medicine, 56:12431 .

Jariyasopit, N., Zimmermann, K., Schrlau, J., Arey, J., Atkinson, R., Yu, T., Daswood, R.H., Tao, S., Simonish, S.L.M. 2014. Heterogeneous reactions of particulate matter-bound PAHs and NPAHs with $\mathrm{NO}_{3} / \mathrm{N}_{2} \mathrm{O}_{5}, \mathrm{OH}$ radicals, and $\mathrm{O}_{3}$ under simulated long-range atmospheric transport conditions: Reactivity and mutagenicity. Environmental Science \& Technology, 48: 10155-10164.

Kamangar, F., Strickland, P.T., Pourshams, A., Malekzadeh, R., Boffetta, P., Roth, M.J., Abnet, C.C., Saadatian-Elahi, M., Rakhshani, N., Brennan, P., Etemadi, A., Dawsey, S.M. 2005. High exposure to polycyclic aromatic hydrocarbons may contribute to high risk of esophageal cancer in northeastern Iran. Anticancer Research, 25: 425-428.

Kuppusamy, S., Thavamani, P., Venkateswarlu, K., Lee, Y.B., Naidu, R., Megharaj, M. 2017. Remediation approaches for polycyclic aromatic hydrocarbons (PAHs) contaminated soils: technological constraints, emerging trends and future directions. Chemosphere, 168: 944-968.

Laffon, B., Pásaro, E., Valdiglesias, V. 2016. Effects of exposure to oil spills on human health: Updated review. Journal of Toxicology and Environmental Health, Part B, 19: 105-128.

LaGoy, P. 1987. Estimated soil ingestion rates for use in risk assessment. Risk Analysis, 7: 355-359.

Lee, S., Hong, S., Liu, X., Kim, C., Jung, D., Yim, U.H., Shim, W.J., Khim, J.S., Giesy, J.P., Choi, K. 2017. Endocrine disrupting potential of PAHs and their alkylated analogues associated with oil spills. Environmental Science: Processes \& Impacts, 19: 1117-1125.

Masuda, M., Wang, Q., Tokumura, M., Miyake, Y., Amagai, T. 2019. Simultaneous determination of polycyclic aromatic hydrocarbons and their chlorinated derivatives in grilled foods. Ecotoxicology and Environmental Safety, 178: 188-194.

Meo, S.A., Al-Drees, A.M., Rasheed, S., Meo, I.M., Al-Saadi, M.M., Ghani, H.A., Alkandari, J.R. 2009. Health complaints among subjects involved in oil cleanup operations during oil spillage from a Greek tanker "Tasman Spirit". International Journal of Occupational Medicine and Environmental Health, 22: $143-8$.

Miller, G.W., Jones, D.P. 2013. The nature of nurture: 
refining the definition of the exposome. Toxicological Sciences, 137: 1-2.

Nøst, T.H., Halse, A.K., Randall, S., Borgen, A.R., Paul, M.S.A., Rahman, A., Breivik, K. 2015. High concentrations of organic contaminants in air from ship breaking activities in Chittagong, Bangladesh. Environmental Science \& Technology, 49: 1137280.

Qu, C., Li, B., Wu, H., Wang, S., Giesy, J.P. 2015. Multipathway assessment of human health risk posed by polycyclic aromatic hydrocarbons. Environmental Geochemistry and Health, 37: 587-601.

Ramesh, A., Archibong, Hood, D.B., Guo, Z., Loganathan, B.G. 2011. Global environmental distribution and human health effects of polycyclic aromatic hydrocarbons. In: Global Contamination Trends of Persistent Organic Chemicals, $1^{\text {st }}$ edition, pp. 97-128, CRC Press, Taylor \& Francis Group, UK.

Rengarajan, T., Rajendran, P., Nandakumar, N., Lokeshkumar, B., Rajendran, P., Nishigaki, I. 2015. Exposure to polycyclic aromatic hydrocarbons with special focus on cancer. Asian Pacific Journal of Tropical Biomedicine, 5: 182-189.

Robinson, A.L., Donahue, N.M., Shrivastava, M.K., Weitkamp, E.A., Sage, A.M., Grieshop, A.P., Lane, T.E., Pierce, J.R., Pandis, S.N. 2007. Rethinking organic aerosols: semi volatile emissions and photochemical aging. Science, 315: 1259-1262.

Sakshi, Haritash, A.K. 2020. A comprehensive review of metabolic and genomic aspects of PAH degradation. Archives of Microbiology, 202: 20332058.

Shahsavari, E., Adetutu, E.M., Ball, A. 2014. Phytoremediation and necro-phytoremediation of petrogenic hydrocarbon- contaminated soils. In: Phytoremediation: Management of Environmental Contaminants, Ansari, A., Gill, S., Gill, R., Lanza, G., Newman, L. (eds.), pp. 321-334, Springer, Cham. Switzerland.

Siddiqi, H.A., Munshi, A. 2015. Tasman Spirit Oil Spill at Karachi coast, Pakistan. In: Handbook of Oil Spill Science and Technology, Fingas, M. (ed.), pp. 557-573, John Wiley \& Sons, Inc. New Jersey, USA.

Smith, R. 1994. Use of Monte Carlo simulation for human exposure assessment at a superfund site. Risk Analysis, 14: 433-439.

Sobus, J.R., DeWoskin, R.S., Tan, Y.M., Pleil, J.D., Philips, M.B., George, B.J., Christensen, K.,
Schreinemachers, D.M., Wiliams, M.A., Hubal, E.A.C., Edwards, S.W. 2015. Uses of NHANES biomarker data for chemical risk assessment: trends, challenges, and opportunities, Environmental Health Perspectives, 123: 919-927.

Stanek, E.J., Calabrese, E.J., Zorn, M. 2001. Soil ingestion distributions for Monte Carlo risk assessment in children. Human and Ecological Risk Assessment, 7: 357-368.

Tabatabaei, S.M., Heyworth, J.S., Knuiman, M.W., Fritschi, L. 2010. Dietary benzo[a]pyrene intake from meat and the risk of colorectal cancer. Cancer Epidemiology, Biomarkers \& Prevention, 19: 31823184.

Tarafdar, A., Chawda, S., Sinha, A. 2020. Health risk assessment from polycyclic aromatic hydrocarbons (PAHs) present in dietary components: a metaanalysis on a global scale. Polycyclic Aromatic Compounds, 40: 850-861.

USEPA. 2008. Child-specific Exposure Factors Handbook, pp. 1-679, Washington, DC, USA.

USEPA. 2004. Risk Assessment Guidance for Superfund vol. I: Human Health Evaluation Manual (Part E, Supplemental Guidance for Dermal Risk Assessment), pp. 1-156, Washington DC, USA.

USEPA. 2000. Deposition of Air Pollutants to the Great Waters: Third Report to Congress. Office of Air Quality Planning and Standards, pp. 1-270, Washington DC, USA.

USEPA. 1997. Exposure Factors Handbook (Final Report), pp. 1-1216, Washington DC, USA.

Wang, R., Tao, S., Wang, B., Yang, Y., Lang, C., Zhang, Y., Hu, J., Ma, J., Hung, H. 2010. Sources and pathways of polycyclic aromatic hydrocarbons transported to Alert, the Canadian High Arctic. Environmental Science \& Technology, 44: 10171022.

Wang, Z.S., Wu, T., Duan, X.L., Wang, S., Zhang, W.J. 2009. Research on inhalation rate exposure factors of Chinese residents in environmental health risk assessment. Research of Environmental Sciences, 22: 1171-1175.

Wang, Z., Liu, S.Q., Chen, X.M., Lin, C.Y. 2008. Estimates of the exposed dermal surface area of Chinese in view of human health risk assessment. Journal of Safety and Environment, 8: 152-156.

WHO. 2000. Air Quality Guidelines for Europe, pp. 92-96, WHO Regional Office, Copenhagen, Denmark.

Wu, W., Ning, Q.N., He, W., He, Q., Ouyang, H., Xu, 
F. 2012. Levels, distribution, and health risks of polycyclic aromatic hydrocarbons in four freshwater edible fish species from the Beijing market. The Science World Journal, 2012: 1-12.

Xiao, G., Li, Y., Ma, G. 2005. Study on weight and height of the Chinese people and the differences between 1992 and 2002. Chinese Journal of Epidemiology, 26: 489-493.

Yebra-Pimentel, I., Fern'andez-Gonz'alez, R., Mart'inezCarballo, E., Simal-G'Andara, J. 2015. A critical review about the health risk assessment of PAHs and their metabolites in foods. Critical Reviews in Food Science and Nutrition, 55:1383-1405.

Zelenyuk, A., Imre, D., Beranek, J., Abramson, E.H., Wilson, J., Shrivastava, M. 2012. Synergy between secondary organic aerosols and long range transport of polycyclic aromatic hydrocarbons. Environmental Science \& Technology, 46: 12459-12466.

Zhang, Y., Dong, S., Wang, H., Tao, S., Kiama, R. 2016. Biological impact of environmental polycyclic aromatic hydrocarbons (ePAHs) as endocrine disruptors. Environmental Pollution, 213: 809-824. 